\title{
Jana Pawła II wizja państwa i społeczeństwa a realia współczesnych przemian
}

Przedmiotem opracowania jest nauczanie społeczne Kościoła katolickiego w kwestii relacji, jakie powinny występować między osobą, rodziną, strukturami pośrednimi (do których można zaliczyć m.in. samorząd terytorialny, organizacje społeczne, grupy sąsiedzkie, samopomocowe) oraz państwem. Rozważania poświęcone temu zagadnieniu oparte są na analizie encykliki społecznej Centesimus annus św. Jana Pawła II, która została opublikowana 1 maja 1991 roku. Papieski dokument nie stracił na znaczeniu, pomimo że od jego ogłoszenia minęło 25 lat. Sformułowane w niej zasady mają charakter ponadczasowy. Maciej Zięba uznał ją nawet za „profetyczną, której trafność i wielkie znaczenie objawi się pełniej Kościołowi i światu dopiero w nadchodzącym [obecnym] tysiącleciu”" . Bezpośrednią inspiracją do jej napisania i ogłoszenia była z jednej strony propozycja „odczytania na nowo" encykliki Rerum novarum Leona XIII, w setną rocznicę jej ukazania się, a z drugiej - interpretacja wydarzeń, jakie nastąpiły po 1989 roku (tzw. Jesień Ludów, czyli upadek systemu komunistycznego w Europie Środkowo-Wschodniej) $)^{2}$.

W encyklice papież Polak przywołuje nauczenie społeczne Kościoła, zgodnie z którym społeczna natura człowieka wyraża się nie tylko przez państwo, lecz także poprzez różnego rodzaju społeczności pośrednie tworzące społeczeństwo, zaczynając od rodziny, a kończąc na wspólnotach

1 M. Zięba, Wspólnota polityczna w świetle „Centesimus annus”, w: Jan Paweł II, „Centesimus annus”. Tekst i komentarze, red. F. Kampka, C. Ritter, Lublin 1998, s. 151.

2 Por. P. Matejski, Liberalizm i socjalizm w świetle społecznego nauczania Kościoła, Kraków 1996, s. 49; zob. też: A. Nossol, Przemiany 1989 roku jako nowe wyzwanie dla Kościoła w Europie środkowo-wschodniej, w: Jan Paweł II, „Centesimus annus”. Tekst i komentarze, s. 89-98. 
gospodarczych, społecznych, politycznych czy kulturalnych. Struktury te powinny posiadać własną autonomię względem państwa, którą papież nazywa „podmiotowością" społeczeństwa ${ }^{3}$. Opiera się ona na podmiotowości człowieka, który jest podstawą i celem życia społecznego, ponieważ to on konstytuuje społeczeństwo, nie odwrotnie ${ }^{4}$.

Jan Paweł II daleki jest od przeceniania roli państwa i społeczeństwa, a zwłaszcza od oddzielania dobra wspólnego państwa od dobra osoby5. Myślą przewodnią encykliki Centesimus annus i Rerum novarum Leona XIII, jak i całej nauki społecznej Kościoła, do której papież Polak wielokrotnie się odwołuje, jest poprawnie rozumiana koncepcja osoby ludzkiej i jej niepowtarzalnej wartości, która wynika $\mathrm{z}$ faktu, że została ona stworzona na obraz i podobieństwo Boga (por. Rdz 1, 27). We wszystkich wspólnotach, niezależnie od ich poziomu, kluczową rolę, w rozumieniu Ojca świętego, odgrywa osoba ludzka i to jej powinna być podporządkowana organizacja społeczeństwa czy państwa. Jego zdaniem „ani rynek, ani Państwo nie są celem międzyludzkiego współżycia, ono samo w sobie posiada szczególną wartość, której Państwo i rynek mają służyć”’ ${ }^{\circ}$. W tak zarysowanej wizji życia jednostki i społeczeństwa warunkiem koniecznym jest poszanowanie wolności osoby. Jan Paweł II uważa, że tam, gdzie „organizacja społeczeństwa ogranicza czy wręcz eliminuje sferę wolności, przysługującej obywatelom, tam życie społeczne ulega stopniowemu rozkładowi i zamiera"'. Stąd też różnego rodzaju instytucje i organizacje powinny być konstruowane w taki sposób, aby tworzyły „klimat wolności", który będzie sprzyjał rozwojowi osobowości i kształtowaniu się cywilizacji personalistycznej. Wątek związany z respektowaniem wolności osoby, pozwalający na zakładanie autonomicznych struktur

3 Zob. cA 13; por. M. Zięba, Wspólnota polityczna w świetle „Centesimus annus”, s. 136137; tenże, Papieże i kapitalizm. Od „Rerum novarum” po „Centesimus annus”, Kraków 1998, s. 75 .

${ }^{4}$ Por. W. Chudy, Osoba ludzka w społeczeństwie, w: Katolicka nauka społeczna. Podstawowe zagadnienia z życia społecznego i politycznego, red. S. Fel, J. Kupny, Katowice 2007, s. 34 .

5 J. Majka, Katolicka nauka społeczna. Studium historyczno-doktrynalne, Rzym-Lublin 1987 , s. 233.

${ }^{6}$ CA 49.

7 CA 25.

8 Por. J. Mazur, Ad bonum per politicam. Wybrane zagadnienia z etyki życia politycznego, Lublin 2011, s. 114. 
obywatelskich i przedsiębiorczych w oparciu o podstawowe zasady społeczne jest fundamentem wizji życia społecznego zarysowanej na kartach Centesimus annus Jana Pawła II 9 .

\section{Państwo i społeczeństwo - zagadnienia definicyjne}

W literaturze przedmiotu, a zwłaszcza w socjologii i katolickiej nauce społecznej, przyjmuje się, że społeczeństwo jest historycznie ukształtowaną i zorganizowaną formą życia zbiorowego ludzi, na którą składają się osoby, struktury, grupy, środowiska i instytucje wzajemnie ze sobą powiązane, zintegrowane przez instytucje społeczności nadrzędnych (narodu, państwa). Społeczeństwo jest relatywnie samowystarczalną zbiorowością zajmującą określone terytorium z odpowiednimi warunkami bytu, wspólną kulturą, systemem wartości i normami moralnymi. Tak rozumiana forma zbiorowości stanowi względnie zamknięty układ, który cechuje poczucie odrębności ${ }^{10}$.

Państwo natomiast definiuje się jako formę organizacji zróżnicowanego społeczeństwa, obejmującą ludność żyjącą na określonym terytorium i podlegającą suwerennej władzy politycznej ${ }^{11}$. Państwo nie jest wyłącznie instytucją władzy, składającą się z organizacji urzędów i zarządów, lecz jest również wspólnotą obywateli. Stąd też u podstaw autentycznego myślenia politycznego, kryjącego w sobie roztropną troskę o dobro wspólne, powinna znajdować się odpowiednia koncepcja człowieka ${ }^{12}$. Celem państwa jest przede wszystkim zapewnienie możliwości realizacji dobra wspólnego rozumianego jako stwarzanie takich warunków życia społecznego, aby osoby, rodziny i inne grupy społeczne mogły realizować swoje cele i rozwijać się ${ }^{13}$.

Państwo można określać jako polityczny związek społeczności lub społeczność w formie politycznego związku. Choć jest ono społecznością

9 Por. M. Zięba, Papieże i kapitalizm..., s. 80-81.

${ }^{10}$ Por. J. Szymczyk, Społeczeństwo, w: Encyklopedia katolicka, t. 18, Lublin 2013, kol. 692. Zob. też: Społeczeństwo, w: K. Olechnicki, P. Załęcki, Słownik socjologiczny, Toruń 2002, s. 198.

${ }^{11}$ Por. J. Turowski, Socjologia. Wielkie struktury społeczne, Lublin 2000, s. 111, 115; J. Szczepański, Elementarne pojęcia socjologii, Warszawa 1972, s. 368; A. Zwoliński, Państwo, w: Encyklopedia katolicka, t. 14, Lublin 2010, kol. 1246.

${ }_{12}$ Por. J. Mazur, Ad bonum per politicam..., s. 17.

${ }^{13}$ Por. J. Turowski, Socjologia. Wielkie struktury społeczne, s. 111. 
w rozumieniu prawno-politycznej jedności, to nie należy go utożsamiać ze społeczeństwem. Społeczność bowiem nie rozwija się tylko politycznie, lecz także kulturalnie, religijnie, gospodarczo itp. ${ }^{14}$ Społeczeństwo potrzebuje jednak organizacji państwowej, ponieważ z natury swojej jest skierowane ku państwu, a celem jego działalności powinno być dobro wspólne wszystkich jego członków ${ }^{15}$. W jednym ze swoich listów ksiądz kardynał August Hlond, prymas Polski, wypowiadając się o państwie, tak o nim napisał: „Kościół bezwzględnie przyjmuje państwo jako potrzebę przyrodzoną i jako konieczne następstwo faktu, że człowiek, przez Boga stworzony, ma taką, a nie inną naturę. Państwo nie jest zatem czymś dowolnym, ale warunkiem naturalnego rozwoju ludzkości, która bez instytucji Państwa nie mogłaby osiągnąć swych przeznaczeń ziemskich i popadłaby w nieopisany chaos"16.

W ujęciu Edmunda Wnuka-Lipińskiego życie społeczne rozpościera się między relacją dwojga osób a relacjami między instytucjami formalnymi na poziomie państwa narodowego, a nawet na poziomie globalnym. Socjolog wyodrębnia trzy, wzajemnie przenikające się poziomy życia społecznego: poziom mikro, mezzo oraz makro. Jeden $\mathrm{z}$ obszernych rozdziałów swojej książki pt. Socjologia życia publicznego poświęcił analizie poziomu mezzo, który jego zdaniem wypełnia przestrzeń społeczną między państwem (poziom makro) a rodziną (poziom mikro) ${ }^{17}$. Tę przestrzeń nazwał społeczeństwem obywatelskim, które zdefiniował jako „ogół niepaństwowych instytucji, organizacji i stowarzyszeń cywilnych działających w sferze publicznej. Są to struktury względnie autonomiczne wobec państwa, powstające oddolnie i charakteryzujące się na ogół dobrowolnym uczestnictwem swoich członków"18.

Każde społeczeństwo tworzy struktury pośrednie, a poprzez nie określony ład społeczny. Bez nich, a także bez pewnego zespołu obowiązujących zasad i wartości, podzielanych i uznawanych przez większość, nie byłoby

${ }^{14}$ Por. J. Mazur, Ad bonum per politicam..., s. 157.

${ }_{15}$ Por. T. Borutka, Społeczne nauczanie Kościoła. Teoria i zastosowanie. Podręcznik do katolickiej nauki społecznej, Kraków 2004, s. 192.

${ }^{16}$ List pasterski ks. kard. Augusta Hlonda „O chrześcijańskie zasady życia państwowego”, Gniezno, 23 IV 1932.

${ }_{17}$ Por. E. Wnuk-Lipiński, Socjologia życia publicznego, Warszawa 2008, s. 94, 124.

18 Tamże, s. 119. 
możliwe współżycie w społeczeństwie ${ }^{19}$. Pojawienie się społeczeństwa obywatelskiego uzależnione jest od spełnienia trzech warunków brzegowych, a mianowicie od istnienia: (1) przestrzeni publicznej, która pozwala na instytucjonalizację społeczności pośrednich; (2) niezależnej komunikacji społecznej, która nie jest kontrolowana przez państwo; oraz (3) rynku, na którym dokonywana jest swobodna transakcja wymiany dóbr i usług, wraz z ochroną prywatnej własności ${ }^{20}$. Wnuk-Lipiński nie przeciwstawia społeczeństwa obywatelskiego państwu i odwrotnie. Jego zdaniem trudno bowiem wyobrazić sobie istnienie społeczeństwa obywatelskiego bez jego najistotniejszego punktu odniesienia, czyli państwa. Co więcej, istnienie państwa uznaje on za „najbardziej podstawowy warunek brzegowy demokracji i funkcjonującego w niej społeczeństwa obywatelskiego" ${ }^{21}$. Podobnego zdania są Juan Linz i Alfred Stepan, którzy twierdzą, iż „żadne nowoczesne społeczeństwo obywatelskie nie może być demokratycznie skonsolidowane, jeśli nie funkcjonuje w ramach państwa"22.

Społeczeństwo obywatelskie to jednak nie tylko instytucje i organizacje społeczne. Musi zaistnieć jeszcze coś takiego, jak „obywatelskość”, „obywatelska postawa duchowa” czy „zbiorowa samoświadomość uczestnictwa" ${ }^{23}$. Poczucie obywatelskości jest koniecznym warunkiem pojawienia się postaw obywatelskich i zachowań, które decydują o faktycznym poziomie kultury cywilnej określonej wspólnoty ${ }^{24}$. Aniela Dylus wskazuje na określone „właściwości mentalne” i „przymioty moralne” czy „obywatelski etos”, którymi powinny charakteryzować się osoby zrzeszone w strukturach pośrednich. Jej zdaniem program moralno-duchowej reformy państwa należy zogniskować wokół personalistycznej koncepcji człowieka. Z godności osobowej człowieka wynika bowiem prawo i obowiązek samorealizacji, samoorganizacji i posługiwania bliź-

19 Por. J. Mariański, Społeczeństwo i moralność. Studia z katolickiej nauki społecznej i socjologii moralności, Tarnów 2008, s. 113.

${ }^{20}$ Por. E. Wnuk-Lipiński, Socjologia życia publicznego, s. 122.

${ }^{21}$ Tamże, s. 121.

${ }^{22}$ J. J. Linz, A. Stepan, Problems of democratic transition and consolidation. Southern Europe, South America, and Post Communist Europe, Baltimore-London 1996, s. 7.

${ }^{23}$ Por. R. Dahrendorf, Co zagraża społeczeństwu obywatelskiemu, tłum. M. Łukasiewicz, w: Europa i społeczeństwo obywatelskie. Rozmowy w Castel Gandalfo, red. K. Michalski, Kraków 1994, s. 235.

${ }^{24}$ Por. E. Wnuk-Lipiński, Socjologia życia publicznego, s. 105. 
nim $^{25}$. Wymaga to jednak odbudowy postaw i umiejętności obywatelskich oraz solidarności międzyludzkiej. Miejscem nabywania tego rodzaju doświadczeń są autonomiczne organizacje, działania i kontakty, które wypełniają przestrzeń występującą między jednostką a społeczeństwem, między obywatelem a państwem ${ }^{26}$.

W nauczaniu społecznym Kościoła katolickiego przyjmuje się, że między wspólnotą polityczną i społeczeństwem obywatelskim występuje wzajemne powiązanie i współzależność. Niemniej jednak przywołane formy organizacji nie są równe w hierarchii celów. Państwo istnieje po to, aby służyć społeczeństwu obywatelskiemu, od którego pochodzi, a w konsekwencji również osobom i grupom, które to społeczeństwo tworzą. Społeczeństwo obywatelskie ma przewagę nad wspólnotą polityczną, gdyż stanowi uzasadnienie dla jej istnienia. Państwo powinno bazować przede wszystkim na „subsydiarnej solidarności” osób i społeczności pośrednich. Podmioty społeczeństwa obywatelskiego są bowiem tkanką łączną życia demokratycznego. Natomiast zadaniem państwa jest zapewnienie ram prawnych dla tworzenia się autonomicznych podmiotów społecznych w obrębie tak rozumianego społeczeństwa ${ }^{27}$. Państwo ma także obowiązek interweniowania, jeśli zajdzie taka konieczność, ale ma to robić z poszanowaniem zasady pomocniczości ${ }^{28}$. Umożliwienie uformowania się i działania społeczeństwa obywatelskiego i jego przedstawicieli jest „najlepszym sposobem rozwijania społecznego wymiaru osoby, który w tych działaniach może się wyrazić" ${ }^{29}$.

\section{Wizja państwa i społeczeństwa w encyklice Centesimus annus}

Jan Paweł II oparł wizję społeczeństwa, państwa oraz rynku na czterech kluczowych zasadach życia społecznego: personalizmu, dobra wspólnego,

${ }^{25}$ Por. A. Dylus, Reforma państwa społecznego. Przebudowa strukturalna i przemiana mentalno-moralna, w: Jan Paweł II, „Centesimus annus”. Tekst i komentarze, s. 187-188.

${ }^{26}$ Por. J. Czapiński, Stan społeczeństwa obywatelskiego, w: Diagnoza społeczna 2015. Warunki i jakość życia Polaków. Raport, red. J. Czapiński, T. Panek, Warszawa 2015, s. 319.

${ }_{27}$ Por. D. Pietrzyk-Reeves, Idea społeczeństwa obywatelskiego. Wspótczesna debata i jej źródła, Wrocław 2004, s. 310.

${ }^{28}$ Por. Papieska Rada „Iustitia et Pax”, Kompendium nauki społecznej Kościoła, Kielce 2005, $\mathrm{nr} 417-418$.

${ }^{29}$ Tamże, $\mathrm{nr} 419$. 
solidarności i pomocniczości. Charakterystyczną cechą wymienionych zasad jest to, że są one korelacyjne i relacyjne w stosunku do zasady naczelnej, jaką jest godność osoby ludzkiej ${ }^{30}$. Projekt wizji życia społecznego przedstawiony przez papieża jest antyideologiczny. Jego rdzeniem jest poszanowanie ludzkiej wolności, a politycznym wyrazem - demokratyczne państwo prawa oparte na fundamencie zasad i wartości, będących podstawą porządku prawnego ${ }^{31}$. Ojciec święty zastrzega jednak, że choć Kościół respektuje „słuszną autonomię porządku demokratycznego", to nie ma tytułu do deklarowania się za jakimkolwiek rozwiązaniem instytucjonalnym bądź konstytucyjnym ${ }^{32}$. W ocenie papieża zarówno państwo, jak i całe społeczeństwo zobowiązane jest do obrony dóbr zbiorowych, takich jak środowisko naturalne czy środowisko społeczne człowieka. Dobra te stanowią między innymi ramy wyznaczające przestrzeń, w której człowiek może realizować własne, indywidualne cele ${ }^{33}$. Człowiek z natury swej jest istotą społeczną. Nie jest bytem samowystarczalnym i aby rozwijać się prawidłowo, potrzebuje innych osób. W związku z tym nie może realizować się bez odniesienia do drugiego człowieka, lecz ze swej natury dąży do tego, aby funkcjonować we wspólnocie lub w zinstytucjonalizowanych społecznościach pośrednich (np. w stowarzyszeniach, fundacjach, jednostkach samorządu terytorialnego), z którymi będzie się identyfikował i za pośrednictwem których może określać swoją własną tożsamośćc ${ }^{34}$. W koncepcji Jana Pawła II państwo powinno mieć służebny charakter względem jego obywateli. Osoby potrzebują odpowiednich warunków, aby móc się realizować w społeczeństwie, państwo natomiast powinno im to umożliwić, m.in. przez podniesienie kultury społecznej obywateli, nauczenie ich samodzielnego życia społecznego, rządzenia się i samoorganizowania ${ }^{35}$. Miejscem takiego przygotowania do życia w społeczeństwie jest przede wszystkim rodzina, która jest „pierwszą i podstawową

${ }^{30}$ Por. F. J. Mazurek, Katolicka nauka społeczna - status metodologiczny i główne obszary problemowe, w: Katolicka nauka społeczna..., s. 25.

${ }^{31}$ Por. J. Mazur, Ad bonum per politicam..., s. 161, 181.

${ }^{32}$ Zob. CA 46-47; por. M. Zięba, Wspólnota polityczna $w$ świetle „Centesimus annus”, s. 140, 150; Tenże, Papieże i kapitalizm..., s. 65.

${ }^{33}$ Zob. CA 40.

${ }^{34}$ Por. T. Borutka, Społeczne nauczanie Kościoła..., s. 10o; J. Mazur, Ad bonum per politicam..., s. 23 .

${ }^{35}$ Por. Cz. Strzeszewski, Katolicka nauka społeczna, Lublin 1994, s. 531. 
komórką «ekologii ludzkiej»" ${ }^{36}$, pierwotną w stosunku do jakiejkolwiek innej wspólnoty, społeczeństwa czy państwa ${ }^{37}$. Rodzina jest naturalną wspólnotą, „w której doświadcza się ludzkiego instynktu społecznego" ${ }^{\text {"38 }}$. Nie istnieje ona dla społeczeństwa i dla państwa, lecz to społeczeństwo i państwo istnieją dla rodziny ${ }^{39}$. Rodzina leży bowiem u samych podstaw bytu każdego społeczeństwa, dlatego też wymaga szczególnej troski i ochrony ${ }^{40}$. W obecnych czasach można zaobserwować nasilające się próby osłabiania rodziny, które w efekcie mogą doprowadzić do jej rozkładu oraz przejmowania przez państwo opieki społecznej i wychowawczej nad jej członkami ${ }^{41}$. Tymczasem system wsparcia dla potrzebujących powinien rozwijać się przede wszystkim w oparciu o rodzinę oraz organizacje społeczne i samopomocowe tworzone przez obywateli. Jan Paweł II podkreśla w Centesimus annus, że Kościół od wieków stara się udzielać pomocy potrzebującym w taki sposób, aby ich nie upokarzać i tym samym nie sprowadzać do roli przedmiotu opieki ${ }^{42}$. W opinii Anieli Dylus szczególny akcent należałoby położyć na odbudowę solidarności międzyludzkiej. Przykładem niesprawdzających się rozwiązań są zinstytucjonalizowane formy solidarności w systemach opiekuńczych, które poważnie naruszyły jej osobowy i aretologiczny wymiar. Publiczna „solidarność” prowadzi do depersonalizacji relacji między potrzebującymi a osobami udzielającymi wsparcia. Sprawia, że naturalne więzi społeczne (rodzinne, sąsiedzkie, zawodowe) wydają się zbędne. Taka pomoc jest ponadto niezmiernie kosztowna i uzależnia od państwa ${ }^{43}$. Zdaniem autorki autonomiczne struktury pośrednie wymagają wzmocnienia i wyzwolenia „z krępującego je gorsetu państwowego ubezwłasnowolnienia [...]. W obliczu kryzysu

${ }^{36}$ CA 39.

37 Por. L. Dyczewski, Rodzina, w: Katolicka nauka społeczna..., s. 98.

${ }^{8}$ Papieska Rada „Iustitia et Pax”, Kompendium nauki społecznej Kościoła, nr 213.

39 Por. tamże, nr 214.

$4^{\circ}$ Por. C. Ritter, Kryzys i odbudowa państwa opartego na prawach rodziny. Podmiotowość i suwerenność rodziny jako cel polityki społecznej państwa demokratycznego, w: Jan Paweł II, „Centesimus annus”. Tekst i komentarze, s. 200.

${ }^{41}$ Por. Z. Waleszczuk, Solidarność w nauczaniu Jana Pawła II. Znaczenie pryncypium $w$ świetle encyklik społecznych „Laborem exercens”, „Sollicitudo rei socialis”, „Centesimus annus”, Kraków 2014, s. 210.

42 Por. CA 49.

43 Por. A. Dylus, Reforma państwa społecznego. Przebudowa strukturalna i przemiana mentalno-moralna, s. 187-188; M. Zięba, Papieże i kapitalizm..., s. 82. 
legitymizacji państwa społecznego, generalnego niezadowolenia $\mathrm{z}$ funkcjonowania centralnie zorganizowanych, nieprzejrzystych systemów socjalnych wskazane jest maksymalne uspołecznienie polityki społecznej”" ${ }^{4}$. Zdaniem Jana Pawła II takie społeczności, jak rodzina, środowisko pracy, organizacje obywatelskie, „dojrzewają [...] jako prawdziwe wspólnoty osób i umacniają tkankę społeczną, zapobiegając jej degradacji, jaką jest anonimowość i bezosobowe umasowienie" ${ }^{45}$. Lokalne struktury i podmioty polityki społecznej nie funkcjonują samodzielnie, lecz zależą od człowieka, który je kreuje, nadając im określony kształt. Społeczna natura człowieka jest bowiem fundamentem wszelkich form społeczności ${ }^{46}$. Człowiek, jako istota społeczna, tworzy sieć różnorodnych społeczności i im gęstsza jest ta sieć, tym bardziej umacnia się tkanka życia społecznego, a zarazem podmiotowość społeczeństwa. Państwo natomiast powinno uszanować tę podmiotowość, która przejawia się m.in. w spontanicznym samoorganizowaniu się społeczeństwa ${ }^{47}$.

W społecznym nauczaniu Kościoła katolickiego podkreśla się, iż nie ma doskonałych lub niedoskonałych form ustrojowych, lecz w pewnych warunkach mogą one być odpowiednie lub nie. Papież podkreśla jednak, że „Kościół nie proponuje żadnych modeli” ${ }^{48}$. Zdaniem księdza Józefa Majki „Kościół przez swoją naukę społeczną nie chce tworzyć nowych systemów ani też opowiadać się za żadnym systemem - opowiada się natomiast za człowiekiem" ${ }^{49}$. Kościół ocenia formy ustrojowe przez pryzmat funkcji moralnych, a nie form prawnych. Negatywnie odnosi się do tych form, które służą tylko jednostkom lub części społeczeństwa, a nie dobru ogółu. Natomiast pozytywnie ocenia te, które respektują zasady demokratyczne w stosunku do wszystkich obywateli, a szczególnie prawa człowieka, zasady równości, wolności i sprawiedliwości oraz prawa uczestnictwa w życiu społecznym i publicznym ${ }^{50}$. Państwo ocenia się przede wszystkim ze względu na to, jak zapewnia jednostkowej osobie środki i warunki do realizacji

${ }^{44}$ A. Dylus, Reforma państwa społecznego..., s. 191.

${ }^{45}$ CA 49.

${ }^{46}$ Por. J. Mazur, Ad bonum per politicam..., s. 23.

${ }^{47}$ Por. W. Łużyński, Struktury pośrednie pomiędzy jednostką ludzka a państwem w nauczaniu społecznym Kościoła, Toruń 2008, s. 57-58.

${ }^{48}$ CA 43.

${ }^{49}$ J. Majka, Katolicka nauka społeczna..., s. 239.

${ }^{50}$ A. Zwoliński, Państwo, kol. 1251. 
dobra wspólnego. W opinii przedstawicieli personalizmu respektowanie godności każdej osoby stanowi bowiem obiektywne kryterium dobrego państwa. Godność osoby i dobro wspólne uznawane są za wartości przedkonstytucyjne, których nie poddaje się werdyktowi większości ${ }^{51}$.

Maciej Zięba zauważa, że zarysowana w Centesimus annus wizja państwa jest daleka od „wszelkich substancjalistycznych i absolutystycznych teorii państwa, a nawet i łagodniejszej wersji myślenia etatystycznego, tak typowej dla socjaldemokracji ostatnich dziesiątków lat, dążenia do "państwa dobrobytu»" ${ }^{2}$. W opinii dominikanina „doświadczenie potęgi i niszczącej mocy państw ideologicznych xx wieku w istotny sposób naznaczyło myślenie Jana Pawła II o państwie" ${ }^{33}$. Skrajnym przykładem radykalnych systemów ideologicznych są państwa totalitarne, które dążą do wchłonięcia narodu, społeczeństwa, rodziny, wspólnot i poszczególnych osób ${ }^{54}$. Ojciec święty odchodzi od myślenia o wspólnocie politycznej jako instytucji władzy pochodzącej od Boga. W encyklice Centesimus annus jednoznacznie przeciwstawia się radykalnym koncepcjom ideologicznym typu indywidualistycznego, jak również dążącym do wchłonięcia społeczeństwa obywatelskiego przez państwo, czemu dał wyraz, poświęcając wiele uwagi analizie przyczyn upadku systemu komunistycznego w krajach Europy Środkowej i Wschodniej. W dokumencie papieskim można znaleźć szereg krytycznych uwag skierowanych pod adresem różnych form współczesnego totalitaryzmu i autorytaryzmu ${ }^{55}$, nacjonalizmu ${ }^{56} \mathrm{czy}$ fundamentalizmu religijnego ${ }^{57}$. Znaczną część społecznej encykliki stanowi także krytyczna analiza rynku pracy i systemów ekonomicznych, głównie socjalizmu i kapitalizmu, które traktują człowieka przedmiotowo. Zdaniem Ojca świętego „nie do przyjęcia jest twierdzenie, jakoby po klęsce socjalizmu realnego kapitalizm pozostał jedynym modelem organizacji gospodarczej" ${ }^{38}$. W jego ocenie należy odrzucić ustrój gospodarczy, w którym dominuje kapitał

${ }^{51}$ Por. W. Chudy, Osoba ludzka w społeczeństwie, s. 56.

${ }^{52}$ M. Zięba, Wspólnota polityczna w świetle „Centesimus annus”, s. 142.

53 Tamże, s. 141; por. tenże, Papieże i kapitalizm..., s. 81-82, 87.

${ }^{54}$ Zob. CA 45.

55 Zob. CA 17-19, 29, 44.

${ }^{56}$ Zob. CA 17.

57 Zob. CA 29; por. M. Zięba, Wspólnota polityczna w świetle „Centesimus annus”, s. 141; tenże, Papieże i kapitalizm..., s. 72, 82.

${ }^{58}$ CA 35. 
oraz własność narzędzi produkcji i ziemi nad podmiotowością człowieka. Analogiczny postulat formułuje pod adresem systemu socjalistycznego, który w rzeczywistości uważa za kapitalizm państwowy. Jan Paweł iI proponuje natomiast alternatywny model: „społeczeństwo, w którym istnieją: wolność pracy, przedsiębiorczość i uczestnictwo" ${ }^{\prime 9}$. Tak rozumiane społeczeństwo nie przeciwstawia się wolnemu rynkowi, ale domaga się odpowiedniej kontroli ze strony sił społecznych i państwa, aby zagwarantować zaspokojenie podstawowych potrzeb całego społeczeństwa. Działalność gospodarcza nie może przebiegać w próżni instytucjonalnej, prawnej czy politycznej. Rolą państwa w dziedzinie gospodarki jest zapewnienie bezpieczeństwa poprzez czuwanie nad przestrzeganiem praw ludzkich w gospodarce i kierowanie nią w taki sposób, aby osoby pracujące mogły korzystać z owoców swojej pracy ${ }^{60}$. Przy czym papież zaznacza, że „główna odpowiedzialność w tym zakresie spoczywa nie na państwie, lecz na pojedynczych osobach i różnych grupach społecznych i zrzeszeniach, z których składa się społeczeństwo" ${ }^{\prime 1}$. Państwo ma natomiast stwarzać warunki dla rozwoju rynku pracy i społeczności pośrednich lub udzielać im wsparcia, jeżeli zaistnieje taka konieczność.

Papież Jan Paweł II wskazuje na szczególną rolę państwa w różnych dziedzinach życia społecznego, które może w wyjątkowych sytuacjach przejmować funkcje zastępcze. Podkreśla jednak szczególne znaczenie współdziałania w rozwiązywaniu problemów społecznych i gospodarczych oraz rolę różnego rodzaju wspólnot i stowarzyszeń, które - zgodnie z zasadą pomocniczości, podstawową zasadą życia społecznego - mają pierwszeństwo przed strukturami wyższego rzędu ${ }^{62}$. Zastępcze interwencje mogą być usprawiedliwione jedynie pilnymi potrzebami, które wiążą się $\mathrm{z}$ realizacją dobra wspólnego ${ }^{63}$. Powinny być jednak ograni-

59 Tamże.

${ }^{60}$ Por. CA 48.

${ }^{61}$ Tamże.

${ }^{62}$ Por. J. Majka, Komentarz do encykliki Jana Pawła II „Centesimus annus”, w: Jan Paweł II, Encyklika „Centesimus annus” Ojca Świętego Jana Pawła II do czcigodnych braci w episkopacie do kapłanów i rodzin zakonnych do wiernych Kościoła Katolickiego i wszystkich ludzi dobrej woli w setna rocznice encykliki „Rerum novarum”, Wydawnictwo Wrocławskiej Księgarni Archidiecezjalnej, Wrocław 1991, s. 132.

${ }^{63}$ Por. R. Buttiglione, J. Merecki, Chrześcijaństwo jako podstawa wspólnego europejskiego domu, w: Jan Paweł II, „Centesimus annus”. Tekst i komentarze, s. 103. 
czone czasowo, aby nie dławić wolności gospodarczej i obywatelskiej. Przeciwieństwem „nieskrępowanego procesu samoorganizowania się społeczeństwa" ${ }^{64}$ są procesy zawłaszczania poszczególnych sfer życia obywateli, ograniczające ich autonomię (np. poprzez obciążanie ich nadmiernymi podatkami, zawłaszczanie przez administrację publiczną kolejnych sfer życia obywateli), które prowadzą do zniechęcenia, apatii, a w rezultacie do zaniku zaangażowania obywatelskiego i politycznego. Przykładem nadmiernego i piętnowanego przez papieża interwencjonizmu państwowego jest model „państwa opiekuńczego”, które pozbawia społeczeństwo odpowiedzialności, tłumi inicjatywę i przedsiębiorczość obywateli, powoduje utratę ludzkiej energii i prowadzi do przesadnego rozrostu publicznych struktur biurokratycznych ${ }^{65}$.

Podsumowując charakterystykę wizji państwa zarysowanej przez Jana Pawła II w encyklice Centesimus annus, Maciej Zięba zauważa, że „nie jest to państwo opiekuńcze, ale nie jest też nieczułe i bierne, jest służebne wobec społeczeństwa, ale nie pasywne i choć ograniczone, to nie znaczy, że słabe" ${ }^{66}$. Jego zdaniem papież nie proponuje modelu idealnego państwa, jedynie kreśli ramy, w jakich powinno ono funkcjonować. Na jednym biegunie umiejscowił jego totalitarne aspiracje, a na drugim - jego liberalną wersję, samoczynne mechanizmy polityczne i ekonomiczne, które nim kierują. Pomiędzy nimi znajduje się przestrzeń, którą powinno wypełnić „upodmiotowione społeczeństwo”, i to jemu poświęcił najwięcej uwagi w swojej encyklice ${ }^{67}$.

Jan Paweł II postuluje oprzeć relację pomiędzy państwem i społeczeństwem na zasadzie pomocniczości ${ }^{68}$. Zgodnie $\mathrm{z}$ tą zasadą inicjatywy podejmowane przez jednostki, rodziny i struktury obywatelskie mają pierwszeństwo przed interwencją jednostek administracji publicznej. Obowiązkiem państwa i samorządów jest tworzenie możliwości sprzyjających rozwojowi społeczeństwa obywatelskiego i zwiększających jego autonomię. Chodzi o kształtowanie warunków pozwalających na proces spontanicznego samoorganizowania się obywateli we wspólnoty,

\footnotetext{
${ }^{64} \mathrm{CA} 16$.

${ }^{65}$ Zob. CA 48

${ }^{66}$ M. Zięba, Wspólnota polityczna w świetle „Centesimus annus”, s. 144-145.

${ }^{67}$ Por. tamże; tenże, Papieże i kapitalizm..., s. 87.

${ }^{68}$ Zob. CA 15, 48.
} 
zdolne do samodzielnego zaspokajania własnych potrzeb i oczekiwań. Interwencja administracji publicznej, w tym samorządowej, powinna być podejmowana jedynie w wyjątkowych sytuacjach.

Zasada pomocniczości jest prawem zapisanym w Konstytucji Rzeczypospolitej Polskiej ${ }^{69}$ i innych aktach normatywnych, niższego rzędu ${ }^{70}$, ale też zobowiązaniem obywateli do współuczestnictwa w budowaniu wspólnoty lokalnej. W praktyce jej założenia sprowadzają się do zwiększania autonomii społeczności lokalnych m.in. przez delegowanie uprawnień i zadań publicznych, wraz z instrumentami (m.in. prawnymi czy finansowymi) niezbędnymi do ich prawidłowej realizacji, podmiotom znajdującym się możliwie jak najbliżej obywatela, np. jednostkom samorządu terytorialnego czy strukturom inicjowanym przez samych obywateli (stowarzyszenia, fundacje, grupy samopomocy itp.).

Społeczności pośrednie odgrywają istotną rolę, ponieważ umożliwiają uczestnictwo w życiu społeczno-gospodarczym. Tworzą przestrzeń publicznego działania dla obywateli, dzięki czemu mogą oni wpływać na najbliższe otoczenie, w ramach społeczności lokalnej czy w skali regionalnej ${ }^{71}$. Jedyną granicę autonomii społeczności pośrednich w stosunku do władz publicznych stanowi dobro wspólne całej społeczności. Zastrzeżenie to wynika przede wszystkim $\mathrm{z}$ ogromnego zróżnicowania i nierówności, jakie często występują wśród instytucji społeczeństwa obywatelskiego czy struktur samorządowych. Obok małych społeczności, dysponujących niewielkim potencjałem ekonomicznym czy organizacyjnym (np. ubogie gminy wiejskie, a w przypadku organizacji społecznych koła gospodyń wiejskich, grupy samopomocowe itp.), istnieją podmioty większe i bogatsze (np. gminy miejskie, szczególnie największe miasta w Polsce, duże organizacje pozarządowe o milionowych przychodach rocznych), dysponujące na tyle pokaźnym kapitałem, że mogą znacząco oddziaływać na większe od siebie struktury społeczne (np. na instytucje samorządowe czy państwowe), aby wywalczyć dla siebie różnego rodzaju przywileje i korzyści.

${ }^{69}$ Zob. Preambuła Konstytucji Rzeczypospolitej Polskiej z dnia 2 kwietnia 1997 r., Dz.U. Z 1997, nr 78 poz. 483 .

70 Przykładem może być chociażby Ustawa o samorządzie terytorialnym z dnia 8 marca 1990 r. (Dz.U. z 1990, nr 16 poz. 95, z późn. zm.), która już na samym początku podkreśla, że to „mieszkańcy gminy tworzą z mocy prawa wspólnotę samorządową" (art. 1).

${ }^{71}$ Por. W. Łużyński, Struktury pośrednie pomiędzy jednostką ludzka a państwem..., s. 21, 254. 
Słuszna autonomia społeczności pośrednich nie może zatem oznaczać zgody na działania, które sprzeciwiają się dobru wspólnemu, lecz wymaga uruchomienia procesów solidarnościowych ${ }^{72}$. O ile zasada subsydiarności zabezpiecza autonomię osób, rodzin i społeczności pośrednich, o tyle zasada solidarności określa granice realizacji dobra wspólnego. Solidarna działalność musi kierować się dobrem wspólnym, które nie jest tylko sumą interesów jednostkowych, lecz wymaga ich oceny i pogodzenia według sprawiedliwej hierarchii wartości. Gwarantem dobra wspólnego jest tylko takie państwo, które będzie się kierowało troską o najsłabszych oraz o ochronę dóbr zbiorowych, których nie da się osłaniać zwykłymi mechanizmami rynkowymi ${ }^{73}$. Zasada solidarności, nazywana również zasadą równowagi społecznej, jest jedną „z fundamentalnych zasad chrześcijańskiej koncepcji organizacji społecznej i politycznej"74. Solidarność jest podstawą wspólnoty i wszelkich innych pośrednich społeczności. Kształtuje stosunki w społeczeństwie, dlatego też stanowi punkt wyjścia dla oddolnej budowy społeczeństwa i państwa. Solidarność jest jednoczesną troską o zabezpieczenie osoby ludzkiej i jej praw oraz dobra wspólnego i praw społeczności ${ }^{75}$. Uważa się ją za konstytutywną cechę osoby ludzkiej, ponieważ wyrasta bezpośrednio $\mathrm{z}$ natury człowieka. Wynika ona $\mathrm{z}$ faktu, że człowiek istnieje wspólnie z innymi i z nimi współdziała. Solidarności człowiek uczy się przede wszystkim w rodzinie, a także poprzez społeczności pośrednie, m.in. w ramach wolontariatu ${ }^{76}$.

Z jednej strony państwo powinno szanować szeroką autonomię wewnętrzną organizacji społeczeństwa, a z drugiej współdziałać w organizowaniu tych wspólnot i koordynować ich działania, by w ten sposób zapewnić jeden porządek społeczny nakierowany na realizację dobra ogólnego zgodnie z poszanowaniem zasady zarówno pomocniczości, jak i solidarności. Zasada pomocniczości jest komplementarna wobec zasady solidarności. Ze współdziałania tych zasad wynika konieczność przestrzegania przez państwo szerokiej autonomii wewnętrznej organizacji

\footnotetext{
72 Por. J. Kupny, Podstawowe zasady życia społecznego, w: Katolicka nauka społeczna..., s. 85.

${ }_{73}$ Zob. CA 8, 10, 40; por. Z. Waleszczuk, Solidarność w nauczaniu Jana Pawła II..., s. 118, $124,12-128,138$.

${ }^{74}$ CA 10.

${ }^{75}$ Por. J. Höffner, Chrześcijańska nauka społeczna, tłum. I. Bokwa, Warszawa 1999, s. 46.

${ }^{76}$ Por. CA 49.
} 
społeczeństwa, jak również konieczność współudziału w organizowaniu różnorodnych wspólnot społecznych w określone społeczności i „koordynowania ich działalności tak, aby z tej bogatej mozaiki form życia społecznego powstał jeden organizm, jeden porządek społeczny, skierowany ku realizacji dobra ogólnego całej społeczności państwowej”77. Zakres uprawnień przekazywanych społecznościom pośrednim powinien być zależny od dojrzałości społeczeństwa. Większa kontrola i interwencja ze strony państwa powinna być przede wszystkim tam, gdzie występują młode i niedoświadczone podmioty obywatelskie i samorządowe oraz niska kultura społeczna i współdziałania. Interwencjonizm państwowy musi być jednak ograniczony w czasie, aby nie doprowadzić do uzależnienia ich od wsparcia ze strony państwa ${ }^{78}$.

Poszanowanie i właściwe rozumienie zasad społecznych, szczególnie zasady personalizmu, dobra wspólnego, solidarności i pomocniczości, jest warunkiem uznania wartości społeczności pośrednich, które wypełniają przestrzeń społeczną między społecznością reprezentowaną przez państwo a osobami ${ }^{79}$.

\section{Aktywność społeczna Polaków na tle innych krajów UE}

Postulowana przez Jana Pawła II wizja społeczeństwa i państwa nabiera szczególnego znaczenia w kontekście przemian ustrojowych, jakie zachodzą w krajach Europy Środkowej i Wschodniej, w których komunizm doprowadził do zniszczenia autonomicznych organizacji społecznych i poważnego osłabienia postaw obywatelskich. Wszystkie kraje postkomunistyczne do dziś zmagają się z odziedziczonym po poprzednim systemie deficytem zaufania społecznego i współdziałania na rzecz dobra wspólnego ${ }^{80}$. Społeczności pośrednie w tych krajach nie są jeszcze w pełni ukształtowane, co potwierdzają prezentowane poniżej wyniki międzynarodowych i krajowych badań. Ich odbudowa będzie wymagała

77 Cz. Strzeszewski, Katolicka nauka społeczna, s. 531.

${ }^{78}$ Por. tamże, s. 533.

79 Por. T. Borutka, J. Mazur, A. Zwoliński, Katolicka nauka społeczna, Częstochowa-Jasna Góra 2004, s. 239.

${ }^{80}$ Por. A. Miszalska, Erozja więzi społecznej w III Rzeczpospolitej, w: Obszary ładu i anomii. Konsekwencje i kierunki polskich przemian, red. A. Miszalska, A. Piotrowski, Łódź 2006, s. 143 . 
czasu, istotnego wsparcia ze strony instytucji państwowych, a przede wszystkim zmiany świadomości społeczeństwa, którą na ten moment charakteryzuje wyuczona bezradność, indywidualizm i niski poziom rozpowszechnionych wzorów aktywności społecznej.

Jednym z istotnych wskaźników aktywności społecznej jest poziom przynależności i uczestnictwa Polaków w działalności organizacji społecznych. Członkostwo w organizacjach uznawane jest za jeden z najlepszych wskaźników kapitału społecznego. Odsetek osób należących do organizacji służy najczęściej za podstawę oceny społecznej aktywności ${ }^{81}$. Wyniki badań w zakresie przynależności obywateli do organizacji społecznych są jednak mocno zdeterminowane przyjętą metodologią badawczą. Większość z nich (m.in. Eurobarometr, своs, овор, Diagnoza społeczna) wskazuje jednak na niski poziom zaangażowania Polaków w działalność organizacji obywatelskich.

Analiza dostępnych raportów i opracowań w zakresie kondycji społeczeństwa obywatelskiego w krajach Europy Środkowej i Wschodniej wykazała, że jego struktury nie są jeszcze w pełni ukształtowane, mimo iż od upadku komunizmu minęło ponad 25 lat. Przykładowo wyniki badań, które przeprowadzono w ramach Eurobarometru 2013 w 27 krajach Unii Europejskiej na próbie ponad 25,5 tys. osób, wyraźnie pokazują dystans, jaki dzieli państwa postkomunistyczne (Czechy, Słowenia, Słowacja, Polska, Bułgaria, Węgry, Estonia, Łotwa, Litwa, Rumunia) od krajów zachodnich (Luksemburg, Austria, Irlandia, Francja, Niemcy, Holandia, Hiszpania, Belgia, Wielka Brytania, Malta, Portugalia, Grecja, Włochy, Cypr), a zwłaszcza skandynawskich (Szwecja, Finlandia, Dania), które wyróżniają się na tle pozostałych państw. W Polsce w działalność instytucji społecznych angażuje się zaledwie $9 \%$ obywateli. Porównywalne wskaźniki występują także w innych państwach, w których panował komunizm, podczas gdy średnia unijna jest ponad dwukrotnie wyższa. W krajach skandynawskich poziom przynależności do organizacji

${ }^{81}$ Por. M. Grewiński, S. Kamiński, Obywatelska polityka społeczna, Warszawa 2007, s. 111-112; P. Gliński, Aktywność aktorów społecznych - deficyt obywatelstwa wobec codziennej zaradności Polaków, w: Kręgi integracji i rodzaje tożsamości. Polska. Europa. Świat, red. W. Wesołowski, J. Włodarek, Warszawa 2005, s. 226; K. Piątek, Organizacje pozarządowe jako podmioty polityki społecznej, w: Praca socjalna w organizacjach pozarządowych. Z problemów działania i kształcenia, red. B. Kromolicka, Toruń 2005, s. 31. 
obywatelskich jest znacznie wyższy, aktywność w tych podmiotach deklaruje od $30 \%$ do nawet $46 \%$ obywateli (zob. wykres 1$)^{82}$.

Wykres 1. Deklarowana przynależność obywateli danego kraju UE (27) do organizacji gospodarczych, społecznych, środowiskowych, kulturowych i sportowych, Eurobarometr $2013(\mathrm{~N}=25551)$

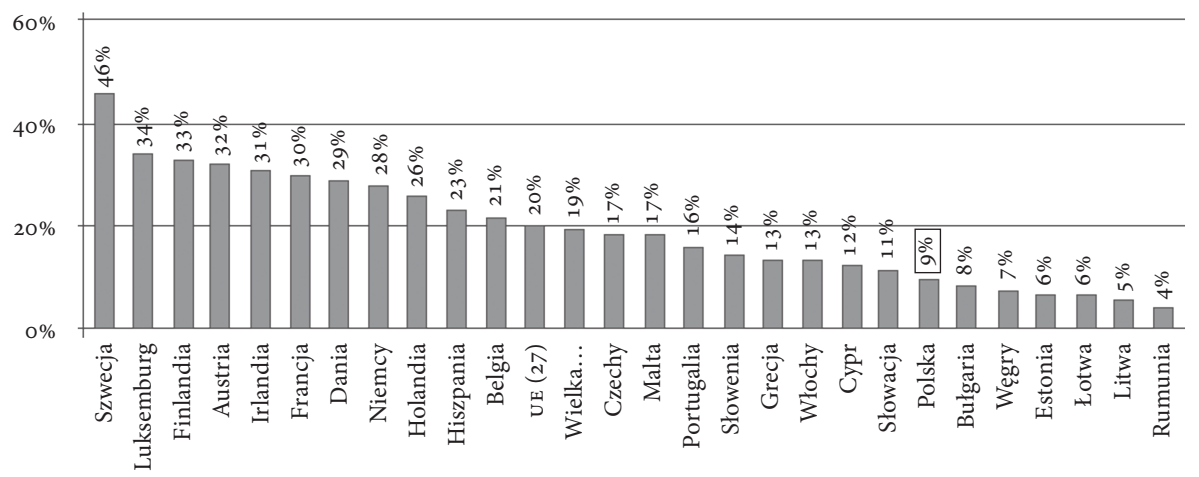

Źródło: opracowanie własne na podstawie Europeans' engagement in participatory democracy. Report, Flash Eurobarometer 373, TNs Political \& Social, III 2013, s. 33.

W ramach Eurobarometru 2013 respondentów pytano również o przynależność do innych typów organizacji społecznych, stowarzyszeń zawodowych (na przykład lekarzy, nauczycieli, rolników), izby gospodarczej, przemysłowej lub rolniczej czy organizacji pracodawców. Badania wykazały, że ponad połowa z nich nie należy do żadnej organizacji (świadczy o tym średnia unijna - 56\%). Najwięcej takich osób jest w krajach postkomunistycznych (w przypadku Słowenii i Czech jest to odpowiednio $62 \%$ i $64 \%$, a w pozostałych - od $73 \%$ do nawet $84 \%$ badanych), a najmniej w krajach skandynawskich (19\%-21\% respondentów). W Polsce w 2013 roku w działalność przywołanych organizacji angażowało się tylko $26 \%$ obywateli (zob. wykres 2).

${ }^{82}$ Por. Europeans' engagement in participatory democracy. Report, Flash Eurobarometer 373, TNS Political \& Social, III 2013, s. 33. 
Wykres 2. Odsetek badanych w krajach UE 27, którzy nie należą do żadnej organizacji społecznej, Eurobarometr $2013(\mathrm{~N}=25551)$

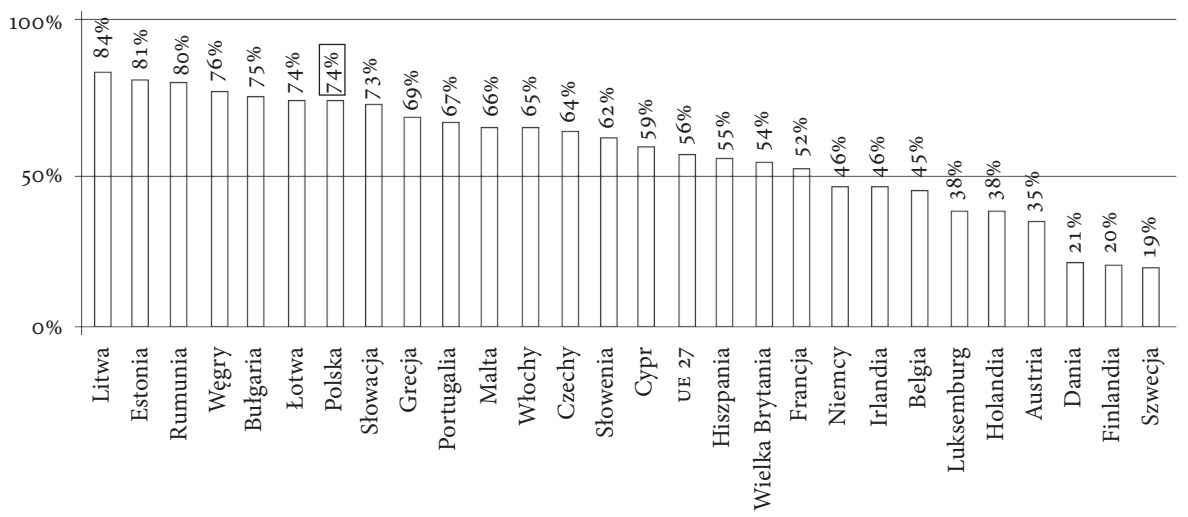

Źródło: opracowanie własne na podstawie Europeans' engagement in participatory democracy. Report, Flash Eurobarometer 373, s. 33.

Wyniki badań Eurobarometru z 2013 roku potwierdzają także znaczące ośrodki badawcze w Polsce. Przykładowo badania Centrum Badania Opinii Społecznej (своS) z 2014 roku wykazały, że aktywność społeczną $\mathrm{w}$ ramach organizacji obywatelskich lub innych instytucji podejmuje zdecydowana mniejszość Polaków. Tylko co piąty badany (19\%) w ciągu ostatniego roku poprzedzającego badanie poświęcił swój wolny czas na dobrowolną i nieodpłatną pracę w ramach jakiejś organizacji pozarządowej (stowarzyszenia lub fundacji), instytucji Kościoła czy innej organizacji, np. w komitecie rodzicielskim, kole parafialnym, ochotniczej straży pożarnej, związku zawodowym, klubie, kole gospodyń wiejskich, wspólnocie mieszkaniowej, partii lub stronnictwie politycznym itp. (zob. wykres 3$)^{83}$.

\footnotetext{
${ }^{83}$ Por. Aktywność społeczna Polaków, oprac. B. Badora, Komunikat z badań cвos, nr 6o/ 2014, Warszawa, v 2014, s. 7-8.
} 
Wykres 3. Czy w ciągu ostatnich 12 miesięcy poświecił(a) Pan(i) swój wolny czas na dobrowolną i nieodpłatną pracę w ramach jakiejś organizacji pozarządowej (stowarzyszenia lub fundacji), instytucji Kościoła czy innej organizacji?, своs 2014 ( $\mathrm{N}=1098)$

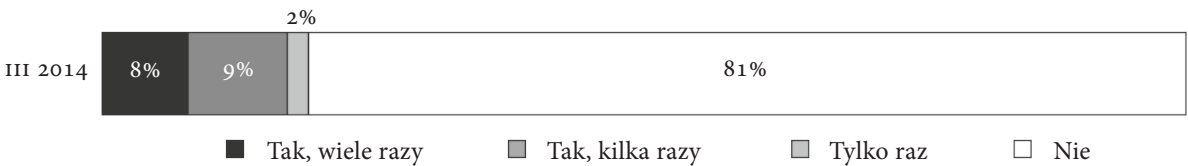

Źródło: Aktywność społeczna Polaków, oprac. B. Badora, Komunikat z badań своs, nr 6o/2014, Warszawa, v 2014, s. 7.

Polacy poświęcają swój wolny czas przede wszystkim osobom z ich najbliższego otoczenia - rodzinie, znajomym, sąsiadom. Im dalszy stopień pokrewieństwa i znajomości, tym mniejszy udział osób angażujących się w dobrowolną i nieodpłatną pomoc (zob. wykres 4).

Wykres 4. Czy w ciągu ostatnich 12 miesięcy poświęcił(a) Pan(i) swój wolny czas na dobrowolną i nieodpłatną pomoc ${ }^{\star}$ na rzecz:

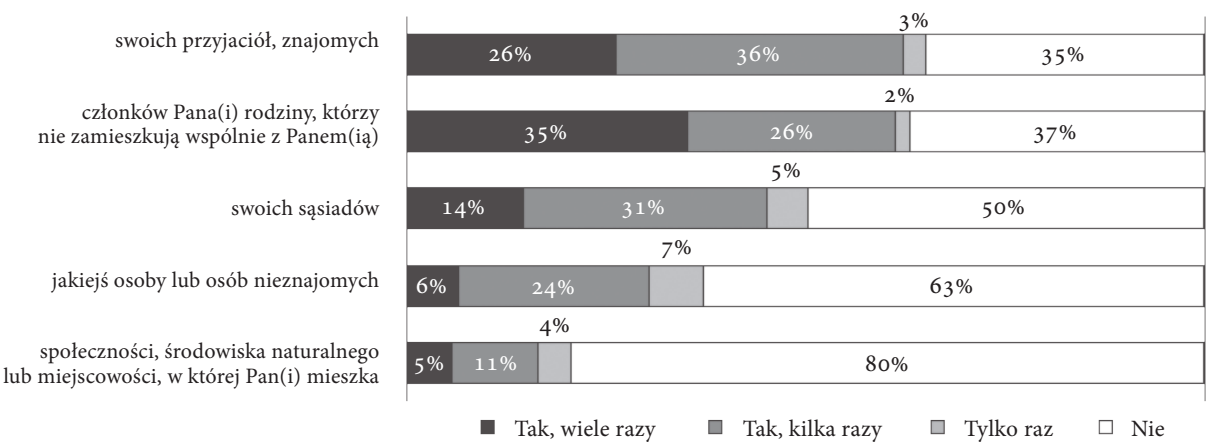

${ }^{\star}$ Chodzi o działania podejmowane indywidualnie, a nie w ramach jakiejś organizacji czy instytucji.

Źródło: Aktywność społeczna Polaków, s. 5.

Wsparcie udzielane swoim przyjaciołom i znajomym deklarowało $65 \%$ ankietowanych, a członkom rodziny, którzy nie mieszkają wspólnie z nimi $-63 \%$ badanych. Do aktywności na rzecz swoich sąsiadów przyznawał się co drugi respondent (50\%), a co trzecia osoba (37\%) deklarowała pomoc nieznajomym. Tylko co piąty badany twierdził, że w ciągu 
ostatnich 12 miesięcy poświęcił swój wolny czas na rzecz społeczności lokalnej, w której mieszka.

Na jeszcze niższy stopień przynależności Polaków do organizacji społecznych wskazują badania Diagnoza społeczna, które w latach 2003, 2005, 2007, 2009, 2011 i 2015 przeprowadził zespół badawczy pod kierunkiem prof. Janusza Czapińskiego. W 2015 roku członkostwo w organizacjach, stowarzyszeniach, partiach, komitetach, radach, grupach religijnych, związkach, kołach zadeklarowało 13,4\% respondentów. Na przestrzeni ostatnich 12 lat (2003-2015) obserwowany jest względnie niski, ale stabilny poziom zainteresowania organizacjami obywatelskimi. Wskaźnik zrzeszania się kształtuje się na poziomie od 12,1\% do 15,1\% (zob. wykres 5).

Wykres 5. Procent osób zrzeszonych w organizacjach społecznych w latach 2003, 2005, 2007, 2009, 2011, 2013 i 2015 wśród badanych w wieku 18 i więcej lat

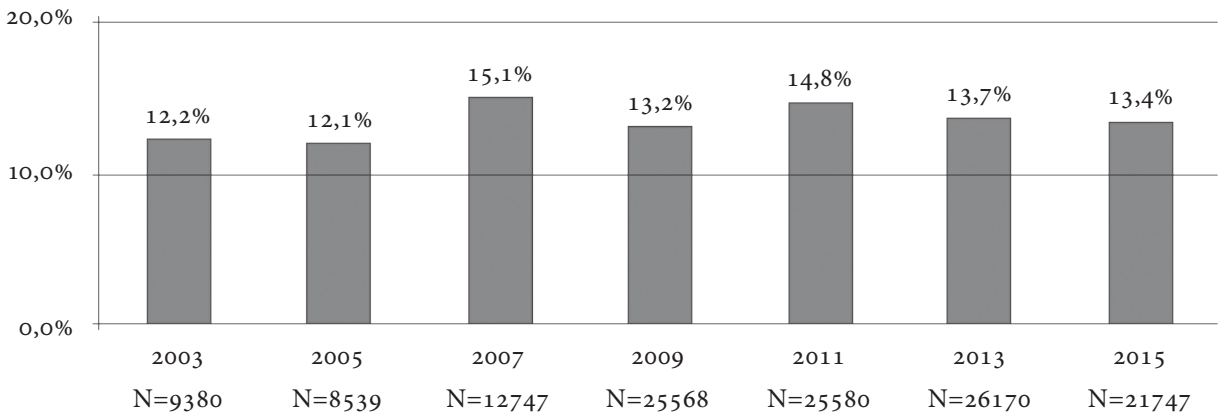

Źródło: opracowanie własne na podstawie J. Czapiński, Stan społeczeństwa obywatelskiego, w: Diagnoza społeczna 2015. Warunki i jakość życia Polaków. Raport, red. J. Czapiński, T. Panek, Warszawa 2015, s. 323.

Zdaniem Czapińskiego uzyskane wyniki badań pokazują, że „społeczeństwo obywatelskie w Polsce, rozumiane jako działanie w organizacjach dobrowolnych, nie rozwija się, nie wciąga w swoje sieci i struktury coraz większej liczby ludzi" ${ }^{84}$. Warto jednak podkreślić, że w porównaniu do lat 9o. wskaźnik osób zrzeszonych w organizacjach społecznych podniósł się ponad dwukrotnie. W 1990 roku przynależność do organizacji pozarządowych deklarowało tylko ok. 5\% Polaków (овоР), pięć

${ }^{84}$ Por. J. Czapiński, Stan społeczeństwa obywatelskiego, s. 323. 
lat później wskaźnik wzrósł już do 13\% (IFiS PAN), w 1999 spadł do 9\%, a w 2002 roku wynosił $12,3 \%^{85}$, natomiast w 2015 roku ukształtował się na poziomie $13,4 \%$.

Ubogie doświadczenia Polaków w zakresie działań obywatelskich są wynikiem przede wszystkim uwarunkowań historycznych. Postawy proobywatelskie były systematycznie osłabiane m.in. w okresie rozbiorów Polski, w czasie I i II wojny światowej. Bariery świadomościowe są także wynikiem dziedzictwa okresu komunistycznego ${ }^{86}$. Zręby społeczeństwa obywatelskiego zbudowane na ogólnopolskim ruchu „Solidarność" z początku lat 8o. okazały się nietrwałe. Zabrakło wówczas autonomicznych wolności obywatelskich i ekonomicznych, pozytywnej relacji obywateli do państwa i państwa do obywateli. Polityka władz Polski Ludowej doprowadziła bowiem do znacznego ograniczenia ducha i postaw obywatelskich. Reperkusją 50 lat komunizmu jest odziedziczony przez naród dystans wobec demokracji i niski stopień identyfikacji z instytucjami mającymi demokratyczny mandat, a w konsekwencji także zmiany w sposobie myślenia i postępowania, które sprzyjały określonej mentalności, przejawiającej się w wycofaniu się z udziału w życiu publicznym i aktywności obywatelskiej oraz braku zaufania do innych osób, instytucji, a nawet autorytetów. Transformacja polityczna i gospodarcza po 1989 roku okazała się niewystarczającą podstawą do wykształcenia się autentycznego społeczeństwa obywatelskiego. W ocenie Doroty Pietrzyk-Reeves „paradoks polega na tym, iż to społeczeństwo obywatelskie, jego instytucje i kultura powinny stanowić ostoję dla instytucji demokratycznych, które w nich mogą znaleźć zakorzenienie. W Polsce ta sytuacja z konieczności została odwrócona [...]"87. Stało się tak m.in. na skutek likwidacji w okresie PRL niezależnych organizacji społecznych, co spowodowało, że potencjał ekonomiczny sektora obywatelskiego po 1989 roku był o wiele słabszy niż w krajach rozwiniętych. Osłabiła się także aktywność obywatelska Polaków, którzy nauczyli się mobilizować przede wszystkim w przypadkach jakiegoś zagrożenia. Za tę sytuację

\footnotetext{
${ }^{85}$ Por. K. Piątek, Organizacje pozarzadowe jako podmioty polityki społecznej, s. 31.

${ }^{86}$ Por. Partycypacja społeczna i aktywizacja $w$ rozwiązywaniu problemów społeczności lokalnych, red. B. Lewenstein, J. Schindler, R. Skrzypiec, Warszawa 2010, s. 10-11; P. Gliński, Aktywność aktorów społecznych..., s. 237-238.

${ }^{87}$ D. Pietrzyk-Reeves, Idea społeczeństwa obywatelskiego..., s. 320.
} 
częściowo odpowiedzialne są również władze III RP, które na początku przemian ustrojowych, a także w późniejszych latach nie zadbały o realizację spójnej polityki wobec sektora obywatelskiego ${ }^{88}$.Zabrakło również głębokiej zmiany społecznej, która powinna towarzyszyć transformacji politycznej i gospodarczej. „Transformacja społeczna” jest jednak najtrudniejszym procesem i trwa najdłużej, wymaga bowiem zmiany świadomości i charakteru ludzi, nastawienia na współdziałanie, a nie na bezustanną konstatację, żąda uczestnictwa i zaangażowania, a nie ciągłego dystansowania się od życia publicznego i przyjmowania biernej postawy, wymaga poszanowania prawa i demokratycznych instytucji, a także obywatelskiej kultury ${ }^{89}$.

Na przestrzeni minionego ćwierćwiecza podjęto wiele wysiłków zmierzających do zwiększenia udziału obywateli Polski w zarządzaniu partycypacyjnym. Począwszy od transformacji systemowej, która miała miejsce na początku lat 9o., i dwuetapowej reformy administracji samorządowej (w latach 1990 i 1999), mamy do czynienia ze stopniowym procesem zwiększania uspołecznienia zarządzania jednostkami samorządu terytorialnego i usprawnieniem wykonywania zadań publicznych, m.in. poprzez przekazywanie części zadań, kompetencji i środków administracji samorządowej jednostkom pomocniczym (w miastach są to osiedla bądź dzielnice, a na wsiach - sołectwa).

Zmiany dotyczyły także odbudowy samoorganizacji obywatelskiej i niezależnych struktur obywatelskich, które stanowią odpowiedź na potrzeby i aspiracje społeczeństwa obywatelskiego w zakresie realizacji własnych celów i potrzeb. W pierwszej dekadzie zmian ustrojowych w Polsce wzajemne relacje administracji publicznej (rządowej i samorządowej) z organizacjami społecznymi cechowały się jednak dorywczością i współpracą ad hoc. W latach 9o. zabrakło spójnego programu ogólnopolskiej strategii rozwoju sektora obywatelskiego. W konsekwencji w okresie pierwszego dziesięciolecia przebudowy modelu społecznego w Polsce rola instytucji społeczeństwa obywatelskiego była mocno ograniczona i sprowadzała się najczęściej do łagodzenia konfliktów społecznych i skutków kryzysu gospodarczego, które powstały po wycofaniu się państwa z części

\footnotetext{
${ }^{88}$ Por. E. Leś, Organizacje non profit w nowej polityce społecznej w Polsce na tle europejskim, Warszawa 2013, s. 137-141.

${ }^{89}$ Por. D. Pietrzyk-Reeves, Idea społeczeństwa obywatelskiego..., s. 320.
} 
zobowiązań o charakterze socjalnym. Relacje administracji publicznej z organizacjami społecznymi w pierwszej dekadzie reform ustrojowych prof. Ewa Leś określa jako „model paralelny z dominującą pozycją administracji publicznej i enklawową rolą sektora organizacji społecznych jako dostawcy usług społecznych i partnera państwa we współtworzeniu polityki społecznej"9o.

W drugiej dekadzie przemian ustrojowych współdziałanie między administracją publiczną i organizacjami społecznymi zostało uregulowane m.in. Ustawą o działalności pożytku publicznego i o wolontariacie ${ }^{91}$. Ustawa pozwoliła na stabilniejsze ulokowanie organizacji społecznych w systemie współpracy międzysektorowej i nieznacznie zwiększyła ich rolę w realizacji polityk publicznych. Dzięki niej wprowadzono szereg instrumentów zwiększających partycypację obywateli w sektorze społeczeństwa obywatelskiego. Ustawa nie rozwiązała jednak wielu kwestii, z którymi borykają się organizacje, przede wszystkim te niewielkie, niedoświadczone i samopomocowe. Najwięcej zastrzeżeń zgłaszanych przez liderów trzeciego sektora dotyczy sposobów finansowania działalności statutowej organizacji i włączania ich w tworzenie oraz realizację polityk publicznych na znacznie większą skalę, niż ma to miejsce obecnie. Potrzebne były kolejne nowelizacje ustawy, które jednak w niewielkim stopniu poprawiły sytuację organizacji społecznych w Polsce. W ocenie badaczy trzeciego sektora stopień implementacji zapisów aktu normatywnego nadal jest niezadowalający. Wnioski odnośnie do wpływu ustawy na poprawę relacji organizacji i instytucji publicznych są umiarkowanie optymistyczne ${ }^{92}$.

Odbudowa zachowań prospołecznych, wyzwolenie oddolnej aktywności jednostek i wspólnot wymaga czasu ${ }^{93}$. Proces kształtowania społeczeństwa obywatelskiego, dochodzenia do coraz większej świadomości obywatelskiej, odpowiedzialności i partycypacji w realizacji dobra wspólnego

\footnotetext{
${ }^{90}$ E. Leś, Organizacje non profit w nowej polityce społecznej w Polsce na tle europejskim, s. 142 .

${ }_{91}$ Ustawa o działalności pożytku publicznego i o wolontariacie z dnia 24 kwietnia 2003 r., Dz.U. z 2003, nr 96 poz. 873, z późn. zm.

${ }_{92}$ Por. E. Leś, Organizacje non profit w nowej polityce społecznej w Polsce na tle europejskim, s. 144-154.

${ }^{93}$ Por. A. Dylus, Reforma państwa społecznego..., s. 186.
} 
trwa przez wiele lat, a często nawet przez kilka pokoleń ${ }^{94}$. Ralf Dahrendorf, komentując falę demokratyzacji w Europie Środkowo-Wschodniej po 1989 roku, napisał: „Formalny proces reformy konstytucyjnej trwa co najmniej sześć miesięcy; ogólne poczucie, że w efekcie reformy gospodarczej idzie ku lepszemu, pojawić się może dopiero po sześciu latach [...]. Społeczeństwa obywatelskiego w ogóle nie da się zbudować, ono musi się ukształtować; ale nie stanie się to w ciągu jednego sezonu czy nawet parlamentarnej kadencji. Sześćdziesiąt lat to może zbyt zniechęcający horyzont czasu potrzebnego, by społeczeństwo obywatelskie rzeczywiście powstało, warunki są różne w różnych krajach i społeczeństwach, ale potrzeba przynajmniej pokolenia [...]"95.

\section{Bibliografia}

Aktywność społeczna Polaków, oprac. B. Badora, Komunikat z badań своs, nr 6o/2014, Warszawa, v 2014.

Borutka T., Mazur J., Zwoliński A., Katolicka nauka społeczna, Paulinianum Wydawnictwo Zakonu Paulinów, Częstochowa-Jasna Góra 2004.

Borutka T., Społeczne nauczanie Kościoła. Teoria i zastosowanie. Podręcznik do katolickiej nauki społecznej, Wydawnictwo „Czuwajmy”, Kraków 2004.

Buttiglione R., Merecki J., Chrześcijaństwo jako podstawa wspólnego europejskiego domu, w: Jan Paweł II, „Centesimus annus”. Tekst i komentarze, red. F. Kampka, C. Ritter, Redakcja Wydawnictw KUL, Lublin 1998, s. 99-114.

Chudy W., Osoba ludzka w społeczeństwie, w: Katolicka nauka społeczna. Podstawowe zagadnienia z życia społecznego i politycznego, red. S. Fel, J. Kupny, Księgarnia św. Jacka, Katowice 2007, s. 31-56.

Czapiński J., Stan społeczeństwa obywatelskiego, w: Diagnoza społeczna 2015. Warunki i jakość życia Polaków. Raport, red. J. Czapiński, T. Panek, Rada Monitoringu Społecznego, Warszawa 2015, s. 314-354.

Dahrendorf R., Co zagraża społeczeństwu obywatelskiemu, tłum. M. Łukasiewicz, w: Europa i społeczeństwo obywatelskie. Rozmowy w Castel Gandalfo, red. K. Michalski, Wydawnictwo Znak, Kraków 1994, s. 222-236.

${ }^{94}$ Por. M. Grewiński, Wielosektorowa polityka społeczna. O przeobrażeniach państwa opiekuńczego, Warszawa 2009, s. 50.

${ }_{95}$ R. Dahrendorf, Rozważania nad rewolucja w Europie, tłum. M. Gottesman, Warszawa 1991, s. 86, 92. 
Dahrendorf R., Rozważania nad rewolucja w Europie, tłum. M. Gottesman, Niezależna Oficyna Wydawnicza, Warszawa 1991.

Dyczewski L., Rodzina, w: Katolicka nauka społeczna. Podstawowe zagadnienia z życia społecznego i politycznego, red. S. Fel, J. Kupny, Księgarnia św. Jacka, Katowice 2007, s. 88-107.

Dylus A., Reforma państwa społecznego. Przebudowa strukturalna i przemiana mentalno-moralna, w: Jan Paweł II, „Centesimus annus”. Tekst i komentarze, red. F. Kampka, C. Ritter, Redakcja Wydawnictw KUL, Lublin 1998, s. 173-191. Europeans' engagement in participatory democracy. Report, Flash Eurobarometer 373, TNs Political \& Social, III 2013.

Gliński P., Aktywność aktorów społecznych - deficyt obywatelstwa wobec codziennej zaradności Polaków, w: Kręgi integracji i rodzaje tożsamości. Polska. Europa. Świat, red. W. Wesołowski, J. Włodarek, Wydawnictwo Naukowe Scholar, Warszawa 2005, s. 221-246.

Grewiński M., Kamiński S., Obywatelska polityka społeczna, Polskie Towarzystwo Polityki Społecznej - Wydawnictwo Wyższej Szkoły Pedagogicznej TwP, Warszawa 2007.

Grewiński M., Wielosektorowa polityka społeczna. O przeobrażeniach państwa opiekuńczego, Wydawnictwo Wyższej Szkoły Pedagogicznej TwP, Warszawa 2009.

Höffner J., Chrześcijańska nauka społeczna, tłum. I. Bokwa, Wydawnictwo Fundacji Aтк, Warszawa 1999.

Jan Paweł II, Encyklika Centesimus annus, przedruk: Libreria Editrice Vaticana, Włocławek 1991.

Konstytucja Rzeczypospolitej Polskiej z dnia 2 kwietnia 1997 r., Dz.U. z 1997, nr 78 poz. 483 .

Kupny J., Podstawowe zasady życia społecznego, w: Katolicka nauka społeczna. Podstawowe zagadnienia z życia społecznego i politycznego, red. S. Fel, J. Kupny, Księgarnia św. Jacka, Katowice 2007, s. 76-87.

Leś E., Organizacje non profit w nowej polityce społecznej w Polsce na tle europejskim, Oficyna Wydawnicza ASPRA-JR, Warszawa 2013.

Linz J. J., Stepan A., Problems of democratic transition and consolidation. Southern Europe, South America, and Post Communist Europe, The Johns Hopkins University Press, Baltimore-London 1996.

List pasterski ks. kard. Augusta Hlonda „O chrześcijańskie zasady życia państwowego", Gniezno, 23 IV 1932, http://naszdziennik.pl/uploads/list-past-ks-karda-hlond.pdf. 
Łużyński W., Struktury pośrednie pomiędzy jednostką ludzką a państwem w nauczaniu społecznym Kościoła, Wydawnictwo Naukowe Uniwersytetu Mikołaja Kopernika, Toruń 2008.

Majka J., Katolicka nauka społeczna. Studium historyczno-doktrynalne, RzymLublin 1987.

Majka J., Komentarz do encykliki Jana Pawła II „Centesimus annus”, w: Jan Paweł II, Encyklika „Centesimus annus” Ojca Świętego Jana Pawła II do czcigodnych braci w episkopacie do kapłanów i rodzin zakonnych do wiernych Kościoła Katolickiego i wszystkich ludzi dobrej woli w setna rocznicę encykliki „Rerum novarum", Wydawnictwo Wrocławskiej Księgarni Archidiecezjalnej, Wrocław 1991.

Mariański J., Społeczeństwo i moralność. Studia z katolickiej nauki społecznej i socjologii moralności, Wydawnictwo BIBLOs, Tarnów 2008.

Matejski P., Liberalizm i socjalizm w świetle społecznego nauczania Kościoła, Wydział Filozoficzny Towarzystwa Jezusowego w Krakowie, Kraków 1996.

Mazur J., Ad bonum per politicam. Wybrane zagadnienia z etyki życia politycznego, Wydawnictwo KUL, Lublin 2011.

Mazurek F. J., Katolicka nauka społeczna - status metodologiczny i główne obszary problemowe, w: Katolicka nauka społeczna. Podstawowe zagadnienia $z$ życia społecznego i politycznego, red. S. Fel, J. Kupny, Księgarnia św. Jacka, Katowice 2007, s. 11-30.

Miszalska A., Erozja więzi społecznej w III Rzeczpospolitej, w: Obszary ładu i anomii. Konsekwencje i kierunki polskich przemian, red. A. Miszalska, A. Piotrowski, Wydawnictwo Uniwersytetu Łódzkiego, Łódź 20o6, s. 143-172.

Nossol A., Przemiany 1989 roku jako nowe wyzwanie dla Kościoła w Europie środkowo-wschodniej, w: Jan Paweł II, „Centesimus annus”. Tekst i komentarze, red. F. Kampka, C. Ritter, Redakcja Wydawnictw KUL, Lublin 1998, s. 89-98.

Olechnicki K., Załęcki P., Słownik socjologiczny, Wydawnictwo Graffiti вс, Toruń 2002.

Papieska Rada „Iustitia et Pax”, Kompendium nauki społecznej Kościoła, Wydawnictwo Jedność, Kielce 2005.

Piątek K., Organizacje pozarzadowe jako podmioty polityki społecznej, w: Praca socjalna $w$ organizacjach pozarządowych. Z problemów działania i kształcenia, red. B. Kromolicka, Wydawnictwo Edukacyjne „Akapit”, Toruń 2005, s. 25-38. Pietrzyk-Reeves D., Idea społeczeństwa obywatelskiego. Współczesna debata i jej źródła, Wydawnictwo Uniwersytetu Wrocławskiego, Wrocław 2004.

Ritter C., Kryzys i odbudowa państwa opartego na prawach rodziny. Podmiotowość i suwerenność rodziny jako cel polityki społecznej państwa demokratycznego, 
w: Jan Paweł II, „Centesimus annus”. Tekst i komentarze, red. F. Kampka, C. Ritter, Redakcja Wydawnictw KuL, Lublin 1998, s. 193-209.

Strzeszewski Cz., Katolicka nauka społeczna, Redakcja Wydawnictw KUL, Lublin 1994.

Szczepański J., Elementarne pojęcia socjologii, PwN, Warszawa 1972.

Szymczyk J., Społeczeństwo, w: Encyklopedia katolicka, t. 18, Towarzystwo Naukowe KUL, Lublin 2013, kol. 692-694.

Turowski J., Socjologia. Wielkie struktury społeczne, Towarzystwo Naukowe KUL, Lublin 2000.

Ustawa o działalności pożytku publicznego i o wolontariacie z dnia 24 kwietnia 2003 r., Dz.U. z 2003, nr 96 poz. 873, z późn. zm.

Ustawa o samorządzie terytorialnym z dnia 8 marca 1990 r., Dz.U. z 1990, nr 16 poz. 95, z późn. zm.

Waleszczuk Z., Solidarność w nauczaniu Jana Pawła II. Znaczenie pryncypium $w$ świetle encyklik społecznych "Laborem exercens”, „Sollicitudo rei socialis”, „Centesimus annus”, Uniwersytet Papieski Jana Pawła II. Wydawnictwo Naukowe, Kraków 2014.

Wnuk-Lipiński E., Socjologia życia publicznego, Wydawnictwo Naukowe Scholar, Warszawa 2008.

Zięba M., Papieże i kapitalizm. Od „Rerum novarum” po „Centesimus annus”, Wydawnictwo Znak, Kraków 1998.

Zięba M., Wspólnota polityczna w świetle „Centesimus annus”, w: Jan Paweł II, „Centesimus annus”. Tekst i komentarze, red. F. Kampka, C. Ritter, Redakcja Wydawnictw KUL, Lublin 1998, s. 133-152.

Zwoliński A., Państwo, w: Encyklopedia katolicka, t. 14, Towarzystwo Naukowe KUL, Lublin 2010, kol. 1246-1252.

\section{Abstrakt}

Ani państwo, ani tym bardziej społeczeństwo (obywatelskie) nie są na tyle samowystarczalne, by samodzielnie podjąć się zadania związanego z kształtowaniem warunków dla rozwoju dobra wspólnego, w którym osoba może realizować własne cele i aspiracje. Demokracja w świetle encykliki Centesimus annus Jana Pawła II wymaga istnienia zarówno państwa, jak i autonomicznego społeczeństwa obywatelskiego, którego wyrazem są różnego rodzaju społeczności pośrednie (rodzina, grupy samopomocowe, stowarzyszenia, fundacje, samorząd lokalny itp.). Nie należy przeciwstawiać państwa społeczeństwu (obywatelskiemu). Obie 
formy życia zbiorowego są komplementarne i powinny się wzajemnie uzupełniać. Papież postuluje, aby relacje pomiędzy nimi oprzeć przede wszystkim na podstawowych zasadach społecznych, a szczególnie na zasadzie personalistycznej, pomocniczości, solidarności i dobra wspólnego.

\title{
John Paul II's vision of state and society a reality of contemporary transformation
}

\begin{abstract}
The state, or the more society (civil society) are not so self-sufficient, to independently take on the task of shaping the conditions for the development of the common good, in which a person can pursue their own goals and aspirations. Democracy in the light of the encyclical Centesimus annus, John Paul II requires the existence of both the state and autonomous civil society, which is reflected in the various types of indirect communities (family, self-help groups, associations, foundations, local government, etc.). Do not oppose the state society (civil). Both forms of collective life are complementary and should complement each other. Pope calls for relations between them rely primarily on basic social principles, especially the principle of personal, subsidiarity, solidarity and the common good.
\end{abstract}

